\title{
Cost Effectiveness and Influence of Storage Bag Type on the Quality of Sweet Potato Vines
}

\author{
I. N. Hlerema ${ }^{1}$, B. Taruvinga ${ }^{1}$, S. M. Laurie ${ }^{1}$, P. Ndou ${ }^{1}$, B. Eiasu ${ }^{2} \&$ C. P. Du Plooy ${ }^{1}$ \\ ${ }^{1}$ ARC-VOP, Roodeplaat, South Africa \\ ${ }^{2}$ University of Fort Hare, Alice, South Africa \\ Correspondence: I. N. Hlerema, ARC-VOP, Roodeplaat, South Africa. E-mail: HleremaI@arc.agric.za
}

Received: October 30, 2017

Accepted: February 7, $2018 \quad$ Online Published: August 15, 2018

doi:10.5539/jas.v10n9p47

URL: https://doi.org/10.5539/jas.v10n9p47

\begin{abstract}
Sweet potatoes present an opportunity for improving food security and income generation in South Africa. The yield of sweet potatoes is highly dependent on the quality of sweet vines used in production. This study aimed at identifying the most cost effective and best storage bag type, between polyethylene and hessian bags, to prolong vine storage. Three bag treatments namely polyethylene bag without holes, polyethylene bag with 12 holes and dry hessian with vines from sweet potato cultivar "Bophelo" were stored for 3, 6, 9, 12 and 15 days at ambient temperature during summer. The costs effectiveness of using different types of bags when transporting and storing vines was calculated using the incremental cost-effectiveness ratio (ICER). The results of the study showed that hessian bags offer the best option to prolong storage (12 days) as compared to polyethylene bags (6 days), however hessian bags are more expensive (R49.10/1 day quality) ( $\$ 4.08$ as at 24/01/2018). Polyethylene bags can be used if the farmer is not willing to pay the additional cost for an addition day of quality. Holes need to be made in polyethylene bags in order to allow air circulation.
\end{abstract}

Keywords: Bophelo, hessian, polyethylene, sweet potato slips, costs

\section{Introduction}

The world population is projected to reach 9.6 billion by 2050 , with most of the growth expected from developing countries, particularly from Africa (UN News, 2013). The challenge of food insecurity of about $50 \%$ of the population in South Africa and malnutrition of more than $40 \%$ of children under 5 years in the country, suggest the need to pay increased attention to food production aspects. Focus on food production need to be directed towards unexploited high nutrient food resources (Mistry, 2014; De Lange, 2010). According to van der Merwe (2011), an improvement in food security transpires if the choice of agricultural technologies, practices and types of crops offer food insecure households an opportunity to produce food or to make food available at affordable prices.

Sweet potatoes present a significant potential for increasing food production, income generation, improving food security and reducing malnutrition in South Africa. Sweet potatoes are high yielding, tolerate occasional dry spells, can grow in less fertile soils and require relatively low agricultural inputs for production (Modi et al., 2011; Niederwieser, 2004). In addition, sweet potatoes can be easily accepted in both production and consumption by low-income populations, as the crop is a popular traditional crop in certain areas of the country (Laurie \& Magoro, 2008). Sweet potatoes are consumed without much processing, mostly eaten boiled, roasted or fried. However, there is a potential growth in household income generation and even industrial use of sweet potatoes, for example in making snacks, flour, baby food, jam, bread and biscuits. Sweet potato roots are a valuable source of carbohydrates, vitamins $\mathrm{B}, \mathrm{C}$ and $\mathrm{E}$, whereas sweet potato vines are a rich source of micronutrients and protein. In particular, orange-fleshed sweet potatoes are rich in beta-carotene; therefore, help fight vitamin A deficiency, which can cause blindness or death among pregnant women and children (Montrone et al., 2009).

Sweet potato is a seasonal crop and grow best in warm temperatures and frost-free areas. In South Africa, sweet potatoes are produced in all provinces, however, Mpumalanga, Limpopo, KwaZulu-Natal and Western Cape provinces are most suitable for sweet potato production (DAFF, 2015). Sweet potatoes are grown using vine cuttings, and their maturity period ranges between 3 and 6 months, depending on the cultivar and production area. 
The majority of smallholder farmers in Southern Africa, including South Africa, rely on vines from the previous year as a source of planting material. Farmers either maintain their own vines in the backyard for replanting purposes or obtain vines from other farmers, neighbours and friends (Thompson et al., 1999). In Africa most seed systems are informal, thus almost all the planting material supplies come from the farmer's field (Gibson et al., 2009). However, the practice of re-using vine material is discouraged because it contributes to the built-up of pests, viruses and diseases on the sweet potatoes, resulting in a drastic reduction in the marketable yield obtainable per unit area (Abidin et al., 2017). The International Potato Centre (CIP) identified that the increase in availability and enhancement of quality of planting material as priority areas for research and development of sweet potato in developing countries (Fuglie, 2007).

A number of initiatives in South Africa encouraged propagation of healthy sweet potato vines by setting up a number of vine nurseries in almost all provinces in the country (Laurie et al., 2015). Virus-tested stock plants are produced by the sweet potato scheme at the Agricultural Research Council-Vegetable and Ornamental Plants (ARC-VOP) (Laurie et al., 2016) and serve as a source of healthy vines for multiplication by vine growers, who are then responsible for supplying healthy planting material to sweet potato producers. Sweet potato vines are also affected by frost, which in turn affect the availability of planting material per location per period of time (Allemann et al., 2004). In temperate areas where the crop cannot retain the foliage during the cold winter, sprouts from the storage roots are the primary source of planting material (Gibson et al., 2009). Thus, areas affected by frost often have limited planting material at the beginning of the production season. Consequently, farmers have to wait in order to accumulate sufficient planting material, which then results in delayed planting, lower yield and lower produce prices (ARC, 2013; Low et al., 2009).

In South Africa, high prices are offered for fresh sweet potatoes between October and December because supplies are often limited during that time of the year (DAFF, 2016). Farmers located in frost-free areas who plant early in the season usually enjoy these prices. Farmers located in areas which experience frost, can also take advantage of high prices by planting early in the season after sourcing sweet potato vines from warm areas. However, when packing and transporting vines, caution needs to be taken to avoid overheating, rotting and drying out of vines. Certain precautionary practices include selecting best possible packaging material that allows good air movement, avoiding overfilling, and stacking too many sacks on top of each other.

After transportation, the vines might require to be stored before being planted, for example as influenced by unfavourable soil moisture conditions, where the soil might be too wet or too dry for planting. In addition, the labour available on the farm might not be able to plant all delivered vines within a day and the weather conditions might be unfavourable for planting, necessitating storage of the vines. Depending on storage conditions and cultivars, vines can be stored for a maximum of seven days, before loosing viability, which leads to a reduction in storage root yield (Niederwieser, 2004). Storing vine cuttings has an advantage of hardening them, thus, vines become tougher and more resistant to the "shock" of planting (International Potato Centre, 2009). During storage, "pre-sprouting" may occur, a condition where roots develop at the base of the cuttings. When pre-sprouted vine cuttings are planted carefully, cuttings establishes faster, although there is no yield advantage from the practice (International Potato Centre, 2009). During storage, the vines require sufficient moisture, aeration and suitable temperature to survive. Generally, in order to extend the number of days that the vines can be stored, the vines require a cool and well-ventilated place. In addition, removing some of the leaves on the cuttings can help extend the storage period. If the vines have to be stored in bags or in a room, then the conditions should allow free air movement, thereby preventing the vines from overheating (International Potato Centre, 2009).

Arguments presented this far in the paper show the need by sweet potato farmers located in areas affected by frost to source vine cuttings from frost free areas, as a way of encouraging early planting and consequently, supporting higher returns. Nonetheless, in South Africa, there is limited literature on the storage methods and period for different sweet potato cultivars, and the types of bags that are recommended for transporting and storing vines. The objectives of this study were: 1 ) to identify the best storage bag type that keeps the vines of the orange-fleshed sweet potato cultivar "Bophelo" in good condition for a longer period and 2) to estimate the costs effectiveness of different bags during transportation and storage of vines.

\section{Method}

\subsection{Vine Storage Experiment}

An experiment was conducted at ARC-VOP, Roodeplaat $\left(25.6048^{\circ} \mathrm{S}, 28.3458^{\circ} \mathrm{E}\right)$ in Gauteng Province of South Africa. Cultivar "Bophelo" was tested with three bag treatments namely polyethylene bag without holes, polyethylene bag with 12 holes and dry hessian bag; each at storage period of 3, 6, 9, 12 and 15 days. The study 
focused on Bophelo (an orange-fleshed cultivar) because the cultivar is currently being promoted in South Africa due to benefits of high in beta-carotene, pleasant taste and good yield (Laurie et al., 2015). The experimental design utilized was a split-plot with period as main plots and 3 bag types as sub-plots replicated twice (Table 1). Sweet potato vines were harvested from the field sweet potato nursery at ARC-VOP during summer in December 2014. The vines were harvested and packed into the different types of bags, and the weight of each bag standardised to $14 \mathrm{~kg}$. The temperature inside the bags were then recorded and the bags were stored in a zinc store facility at ambient temperature. Most upcoming farmers do not have access to cooled facilities. During the storage period the average temperature per day was $27^{\circ} \mathrm{C}$ with average minimum of $16.04{ }^{\circ} \mathrm{C}$ and maximum of $34{ }^{\circ} \mathrm{C}$ and humidity of $58 \%$. Mass of bags was measured every morning using an Olpha digital weighing scale. The temperature inside bags, at the centre was measured once a day in the morning using the digital thermometer During the storage period, 10 vines were randomly selected from each type of bag per storage period, for determination of quality. The quality of vines were recorded using a scale of $1-5$, where, $5=$ very good $(100 \%$ rooting); $4=\operatorname{good}(80 \%$ rooting $) ; 3=$ fair $(60 \%$ rooting $) ; 2=$ bad $(40 \%$ rooting $)$ and $1=$ wilted $(\leq 20$ rooting). The vines were then removed from the bags and 10 vine cuttings were made from the vines. These were left in shallow water for two days where after the root development was recorded.

Table 1. Experimental layout for testing different bag storage treatments for sweet potato vines

\begin{tabular}{lllll}
\hline Rep & Period (Main plot) $\#$ & \multicolumn{3}{l}{ Treatments (Subplots)* } \\
\hline 1 & 1 & 2 & 1 & 3 \\
1 & 5 & 3 & 2 & 1 \\
1 & 2 & 3 & 1 & 2 \\
1 & 3 & 2 & 3 & 1 \\
1 & 4 & 1 & 2 & 3 \\
2 & 3 & 3 & 2 & 1 \\
2 & 2 & 1 & 3 & 2 \\
2 & 5 & 2 & 1 & 3 \\
2 & 1 & 3 & 2 & 1 \\
2 & 4 & 1 & 3 & 2 \\
\hline
\end{tabular}

Note. $\#: 1=3$ days, $2=6$ days, $3=9$ days, $4=12$ days, $5=15$ days; *: $1=$ Polyethylene bag without holes, $2=$ Polyethylene bag with 12 holes, 3 = Dry Hessian bag.

The data was analysed using Statistical Package for Social Sciences (SPSS 22.0). Descriptive statistics such as frequencies were utilized in the analysis, and means were tested using two-factor Analysis of Variance (ANOVA).

\subsection{Cost Effectiveness Analysis}

A cost-effectiveness analysis (CEA) was performed to estimate the cost effectiveness of using different bags when transporting and storing vines. CEA is applied to allow the researcher to choose an action to pursue when presented with more than a single option for performing an action (Levin \& McEwan, 2001). The incremental cost-effectiveness ratio (ICER) was calculated in order to illustrate the difference in cost between two possible types of bags, and the difference in their effect on quality. The function for ICER is:

$$
I C E R=\frac{C_{2}-C_{1}}{E_{2}-E_{1}}
$$

Where, $C_{2}$ and $C_{1}$ are the costs of the different courses of action, whereas $E_{2}$ and $E_{1}$ are the effects of those actions (Levin \& McEwan, 2001).

The three types of costs that were considered in the study were the cost of bags, the cost of transportation and the cost of labour utilized for planting sweet potatoes. To determine total cost of bags per bag type, the number of bags required for transporting vine material was multiplied by the price of bag (polyethylene bags or hessian bags). The cost of transportation was calculated based on the cost charged per kilometre (R4.50/km; USD0.34) based on ARC-VOP rate, total distance and the travelling frequency between source of vine material and the farm where the material is planted. Transport cost was calculated from Tzaneen in Limpopo Province (vine source in frost-free area) to Roodeplaat in Gauteng representing areas affected by frost (where sweet potato is planted). The frequency of travel between the two areas depended on the carrying capacity of the vehicle and the 
number of days, which the vine material can be stored before planting. Thus, the longer the period that the vine material can be stored before planting, the more likely that the full capacity of the vehicle will be utilized and the less likely the frequency of travelling to source vine material. Cost of labour was measured by the wages required in paying additional labour, other than permanent labour, that is required for planting sweet potatoes. Casual labour can be hired to speed up the planting process, implying that vine material will require minimal storage. Of the following assumptions related to the carrying capacity of the vehicle, labour cost, transportation costs per kilometre and labour required per hectare were made:

(1) Carrying capacity of the vehicle (bakkie) is 30 bags of $50 \mathrm{~kg}$ maize size bag filled with vine material;

(2) There are no permanent labourers available on the farm; additional casual labourers can be hired at a cost of R13.40 per person per hour;

(3) Distance between vine source and the farm where the vines are planted is $350 \mathrm{~km}$, where the transport cost is set at R4.50 per kilometer;

(4) Time required to cut and plant vines is 154 hours per hectare;

(5) Buying price of an empty Polyethylene bag is R3.75 and that of a Hessian bag is R16.70.

\section{Results}

\subsection{Quality of Vines}

The effect of storage bag type on the quality of Bophelo vines was statistically significant for all storage periods. A general inverse linear relationship was found between storage period and quality of vines. However, the rate of deterioration is higher for vines stored in polyethylene bags as compared to those in hessian bags. The vines that were stored in the polyethylene bags with no holes started wilting and rotting after day 3 , while those in the polyethylene bags with 12 holes and those in the hessian bags remained firm (Table 2).

Table 2. Quality of sweet potato vines in three packaging treatments over a period of 15 days at ambient temperature

\begin{tabular}{lllllll}
\hline \multirow{2}{*}{ Bag types } & \multicolumn{6}{c}{ Quality of vines-rooting scale } \\
\cline { 2 - 7 } & Day 1 & Day 3 & Day 6 & Day 9 & Day 12 & Day 15 \\
\hline Polyethylene no hole & $5^{\text {a }}$ & $4^{\text {a }}$ & $3^{\text {b }}$ & $2^{\mathrm{c}}$ & $2^{\mathrm{d}}$ & $1^{\mathrm{e}}$ \\
Polyethylene 12 holes & $5^{\text {a }}$ & $4^{\mathrm{a}}$ & $4^{\mathrm{a}}$ & $3^{\mathrm{b}}$ & $2^{\mathrm{c}}$ & $1^{\mathrm{d}}$ \\
Hessian & $5^{\text {a }}$ & $5^{\mathrm{a}}$ & $5^{\mathrm{a}}$ & $4^{\mathrm{a}}$ & $4^{\mathrm{b}}$ & $3^{\mathrm{c}}$ \\
\hline
\end{tabular}

Note. Mean values with different superscript letters in columns and rows differ significantly ( $\mathrm{p} \leq 0.05)$.

$5=$ very $\operatorname{good}(100 \%$ rooting $) ; 4=\operatorname{good}(80 \%$ rooting $) ; 3=$ fair $(60 \%$ rooting $) ; 2=$ bad $(40 \%$ rooting $)$ and $1=$ very bad rooting $(\leq 20$ rooting)

\subsection{Changes in Temperature Inside Bags}

Figure 1 illustrates the changes in temperature inside the bags over a period of time for the stored vines. The temperature inside all the bag types kept on fluctuating throughout the storage period. Except for day 3 and day 12 , the temperature inside the polyethylene bags with no holes had the highest average value, reaching a maximum of $24.2{ }^{\circ} \mathrm{C}$. 


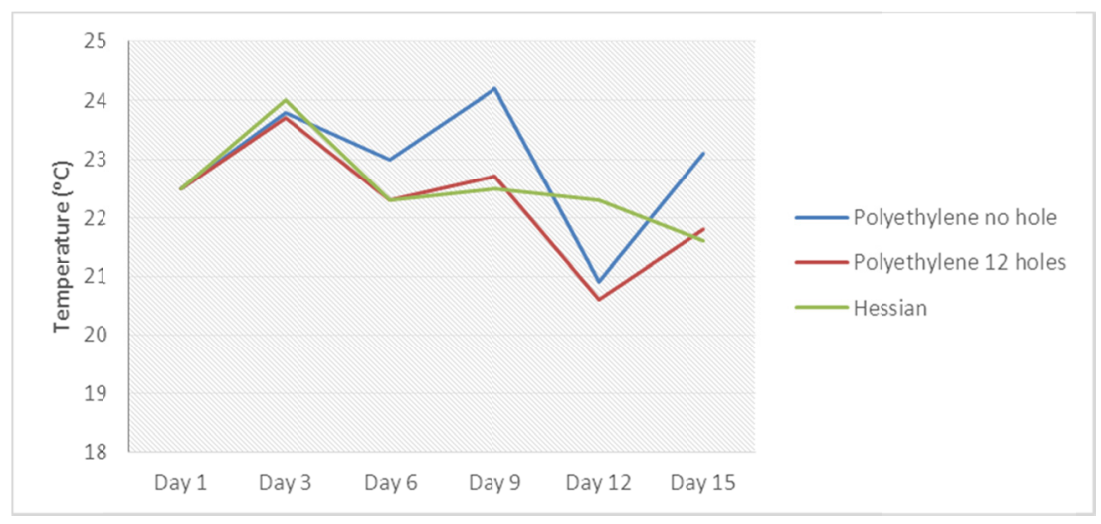

Figure 1. Mean temperature inside different types of bags filled with sweet potato vines

On day 3 , temperature inside the hessian bags had the highest value of $24{ }^{\circ} \mathrm{C}$, which was $0.2{ }^{\circ} \mathrm{C}$ and $0.3{ }^{\circ} \mathrm{C}$ more than that of polyethylene bags with 12 holes and polyethylene bag with no holes respectively.

\subsection{Weight Loss During Storage}

Figure 2 shows that mass decreased with an increase in storage period for all types of bags. From day 3 up to day 6 , the mass of the vines in the hessian bags was the least, then thereafter, the mass stabilized such that by day 12 the mass of the same vines was the highest. The mass of the vines in the polyethylene bag with 12 holes fell gradually, and by day 12 the mass was higher than that of vines in the polyethylene bag with no holes.

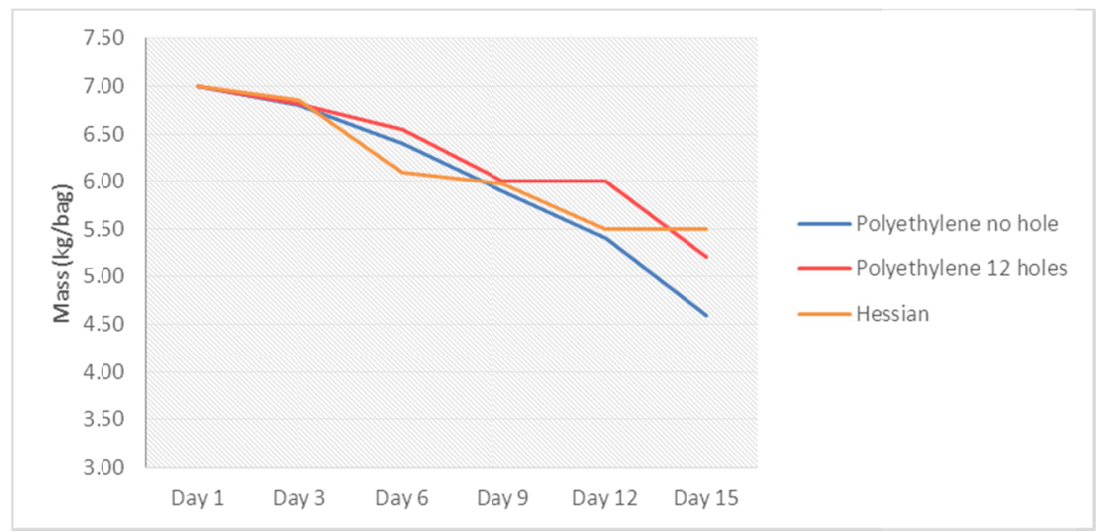

Figure 2. Mass of three different bag types with sweet vines

\subsection{Cost-Effectiveness}

When using polyethylene bags, two options available are transporting a few bags (15 bags) of vines (which can be planted within 6 days) at a time or utilizing the full carrying capacity (30 bags) of the vehicle but hiring additional labour for planting. Cost effective analysis results of the study are presented in Table 3. 
Table 3. Cost effectiveness of the different types of bags (USD1 = ZAR12.02 as at 24/01/2018)

\begin{tabular}{|c|c|c|c|}
\hline & $\begin{array}{l}\text { Option } 1 \\
\text { Polyethylene bags (transport } \\
\text { less than the carrying capacity } \\
\text { of the vehicle) }\end{array}$ & $\begin{array}{l}\text { Option } 2 \\
\text { Polyethylene bags (utilize } \\
\text { the full capacity of the } \\
\text { vehicle) }\end{array}$ & $\begin{array}{l}\text { Option } 3 \\
\text { Hessian bags (utilize the full } \\
\text { capacity of the vehicle) }\end{array}$ \\
\hline Minimum number of bags required and price & 15 bags at R3.75 each & 30 bags at $\mathrm{R} 3.75$ each & 30 bags at R16.70 each \\
\hline $\begin{array}{l}\text { Distance, transportation cost and travelling } \\
\text { frequency }\end{array}$ & $\begin{array}{l}350 \mathrm{~km} \text { one way at } \mathrm{R} 4.50 / \mathrm{km} \text {, } \\
2 \text { trips }\end{array}$ & $\begin{array}{l}350 \mathrm{~km} \text { one way at } \\
\mathrm{R} 4.50 / \mathrm{km}, 1 \text { trip }\end{array}$ & $\begin{array}{l}350 \mathrm{~km} \text { one way at } \\
\mathrm{R} 4.50 / \mathrm{km}, 1 \text { trip }\end{array}$ \\
\hline $\begin{array}{l}\text { Additional amount of labour required (other than } \\
\text { permanent labour) and cost }\end{array}$ & none & 18 hrs@R13.40/hr & none \\
\hline $\begin{array}{l}\text { Number of storage days (offering } 100 \% \text { rooting } \\
\text { percentage) }\end{array}$ & & 6 & 9 \\
\hline Total cost of bags & R56.25 & R112.50 & R501.00 \\
\hline Labour cost (excluding permanent labour) & $\mathrm{R} 0$ & $\mathrm{R} 241.20$ & R0 \\
\hline Transport cost & R6 300.00 & R3 150.00 & R3 150.00 \\
\hline Total cost & R6 356.25 & R3 503.70 & R3 651.00 \\
\hline Effect [quality of vines (days)] & 6 & 6 & 9 \\
\hline Incremental cost-effectiveness ratio (ICER)* & & & R49.10/1 day quality \\
\hline
\end{tabular}

Note. * ICER was calculated between Option 2 and Option 3 only; Option 1 \& Option 2 have the same effect but Option 1 is more costly, implying that it is not costs effective to choose it.

Table 3 shows that polyethylene bags were cheaper as compared to hessian bags, however, polyethylene bags could only keep the vines at almost $80 \%$ rooting percentage up to day 6 , while vines in the hessian bags could keep up to day 9. By comparing the costs and effect offered by the three options presented in Table 3, transporting a few vines at a time (Option 1) increases costs without improving the effect. For this reason, this option is not cost-effective and cannot be recommended. Polyethylene bags can be used for storing vines if additional labour for planting purposes can be hired or if the farmer already has a large labour force (permanent labourers or unemployed family members) that can assist with planting. Since option 1 is very costly, option 2 and option 3 were recommended as the two economical options to choose from.

The cost effectiveness calculations of option 2 and option 3 gave an ICER of R49.10/additional day of quality. This results indicate that option 3 can be chosen over option 2 if the farmer is willing to spend an additional R49.10 for keeping the quality of vines in good condition for an additional day, otherwise if the farmer is not willing to spend more, then option 2 should be taken. However, by choosing option 2, the farmer should understand the need for putting holes on the bags, implying that the bags may probably not be reusable. In all cases, transporting vines from one area to the other can only be considered after comparing the additional costs with the price benefit of sweet potatoes and the resultant effect on profitability.

\section{Discussion}

\subsection{Quality of Vines}

The reason for the difference in the bag storage period is that, hessian bags and polyethylene bags with 12 holes allowed air circulation within the bags. When there is air circulation within the bags, vines are able to respire and gain metabolic energy for maintenance (Simson \& Straus, 2010). On the other hand, the anaerobic conditions in the polyethylene bags without holes promoted rotting of the vines. These results indicate that the decision on the type of bag to use when transporting vines should not barely be based on preferences. However, considerations on the time period that the vines will be stored before planting should be made. If vines are possibly stored for at least a week, then the bag type that allows air circulation should be chosen. A hessian bag has been identified as the type of bag that maintains good quality of stored vines for a longer period of time. As indicated in Table 2, vines that were stored in hessian bags still had a rooting percentage of almost $80 \%$ on day 9 and $60 \%$ on day 15 . Polyethylene bags can be used as an alternative if the vines will be kept for at most 6 days, however, there is need for creating a conducive setting for air circulation when using this type of bag by making holes on the bag. These results are in line with those from International Potato Centre (2009), where air circulation is recommended when storing vines.

\subsection{Changes in Temperature Inside Bags}

The temperature was slightly higher in bags, which allowed air circulation because of the respiratory activities of the vines. According to Simson and Straus (2010), a good supply of air is needed for respiration to occur, and as 
respiration occurs in a closed environment temperature increases within that environment. Respiration occurs even after harvesting, whereby it uses stored starch or sugar, and only stops when the reserves are exhausted. When the air supply is restricted, then fermentation occurs instead of respiration, which leads to rotting. Also, poor ventilation in harvested material leads to carbon dioxide accumulation, which exposes the material to rotting (Bachmann \& Earles, 2000). The process of rotting also releases heat and is the reason for an increase in temperature inside the polyethylene bag with no holes. By day 6 , the temperature inside the polyethylene bag with no holes had the highest value as compared to the other two types of bags. Since air movement was minimal in the polyethylene bag with no holes, temperature could not be regulated easily.

\subsection{Changes in Mass of Bags}

The decrease in mass is attributed to the respiratory activities of the vines. Vines continue to respire after they are cut, and as they do so water is lost from the vines. If there is no means of replacing the lost water, then there will be a resultant shrinkage and loss in mass of the vines. The rate of water loss in a plant is related to the difference between the water vapour pressure inside the plant and in the air. The rate at which water is lost varies according to the atmospheric conditions as well as the type of plant. Plants with broader leaves and many pores tend to lose water quickly, and generally, all plants lose more water under hot conditions as compared to cold conditions (Simson \& Straus, 2010). Since the heat inside the hessian bags was initially high (up to day 3 ) as compared to other bags (Figure 1), then the vines inside the hessian bags lost more moisture, hence a decrease in mass (Figure 2). These results show that there is a correlation between mass and temperature in stored vines. Another possible explanation for the loss of mass of vines in hessian bags is that some water from the vines could have been absorbed by bag. Considering the results on temperature, mass and quality of vines, hessian bags offer the best opportunity for storing vines over a longer period of time as compared to polyethylene bags. However, polyethylene bags can still be used especially if the bags have holes that allow air circulation.

\section{Conclusion}

After sweet potato vines are cut, they can be stored for a number of days in good quality, before they are planted. The ability to store vines allows farmers to obtain vines from frost-free areas to areas that are affected by frost, which often have limited planting material at the beginning of the production season. This allows such farmers to take advantage of high market prices hence high profitability, by planting early in the season. When vines are transported from one area to the other, there is need to monitor the conditions to which the vines are exposed, in order to keep the vines in good condition. This study evaluated the effect of different storage bag types and storage period on the quality of Bophelo vines, and the cost effectiveness of using the different types of bags. The results on temperature, mass and quality of vines led to the conclusion that hessian bags offer the best opportunity for storing vines over a longer period of time as compared to polyethylene bags. After considering the costs, it can be concluded that polyethylene bags can still be used if the farmer is not willing to pay an additional amount of money for additional days of quality but holes need to be put on the bags to allow air circulation.

\section{References}

Abidin, P. E., Akansake, D. A., Asere, K. B., Acheremu, K., \& Carey, E. E. (2017). Effect of source of sweet potato planting material for quality vine and root yield. Open Agriculture, 2017(2), 244-249.

Allemann, J., Laurie, S. M., Thiart, S., \& Vorster, H. J. (2004). Sustainable production of root and tuber crops (potato, sweet potato, indigenous potato, cassava) in southern Africa. South African Journal of Botany, 70(1), 60-66. https://doi.org/10.1016/S0254-6299(15)30307-0

ARC (Agricultural Research Council). (2013). Production Guideline for summer vegetables. Agricultural Research Council, Pretoria.

Bachmann, J., \& Earles, R. (2000). Postharvest handling of fruits and vegetables. Appropriate Technology Transfer for Rural Areas. Retrieved August 18, 2015, from http://www.wnc.edu/files/departments/ce/sci/ postharvesthandling.pdf

DAFF (Department of Agriculture, Forestry and Fisheries). (2016). Crops and markets. Directorate Statistics and Economic Analysis (Vol. 97, pp. 1-37). Department of Agriculture, Forestry and Fisheries.

De Lange, J. C. (2010). Factors contributing to malnutrition in children 0-60 months admitted to hospitals in the Northern Cape. University of the Free State, South Africa. 
Domola, M. J., Laurie, S. M., Thompson, G. J., Strydom, H. D., Van Den Berg, A. A., \& Aveling, T. A. S. (2008). Sweet potato viruses in South Africa and the effect of viral infection on storage root yield. African Plant Protection, 14, 15-23.

Fugle, K. O. (2007). Priorities for sweet potato research in developing countries: Results of a survey. Hort. Sci., 42, 1200-1206.

Gibson, R. W., Mwanga, R. O. M., Namanda, S., Jermiah, S. C., \& Barker, I. (2009). Review of sweet potato seed systems in East and Southern Africa. Integrated pest management working paper (Vol. 1, pp. 48-65). International Potato Center (CIP), Lima, Peru.

International Potato Centre. (2009). Sweet potato seed systems: Training manual for farmers. SASHA Project, Western Kenya.

Laurie S. M., Faber, M., Adebola, P., Belete, A. (2015). Biofortification of sweet potato for food and nutrition security in South Africa. Food Research International, 76, 962-970. https://doi.org/10.1016/j.foodres. 2015.06.001

Laurie, S. M, Myeza, P. N., Mulabisana, M. J., Mabasa, K. G., Thompson, A., Greyling, R., ... Adebola, P. O. (2016). In-vitro propagation and disease testing as a means of producing healthy planting materials to support root and tuber crops production in South Africa. Acta Hort, 1113, 225-232. https://doi.org/ 10.17660/ActaHortic.2016.1113.34

Laurie, S. M., \& Magoro, M. D. (2008). Evaluation and release of new sweet potato varieties through farmer participatory selection. African Journal of Agricultural Research, 3(10), 672-676.

Levin, H. M., \& McEwan, P. J. (2001). Cost-Effectiveness Analysis: Methods and Applications (2nd ed.). Thousand Oaks, CA: Sage Publications.

Low, J., Lynam, J., Lemaga, B., Crissman, C., Barker, G., Thiele, G., ... Andrade, M. (2009). Sweetpotato in Sub-Saharan Africa. In G. Loebenstein, \& G. Thottappilly (Eds.), The Sweetpotato (pp. 359-390). Springer, Heidelberg. https://doi.org/10.1007/978-1-4020-9475-0_16

Mistry, R. (2014). Hidden hunger strips away dignity, perpetuates inequality and destroys South Africans' potential to prosper. Retrieved October 31, 2014, from http:/www.oxfam.org/en/pressroom/pressreleases/ 2014-10-13/south-africa-hunger-strips-away-dignity-perpetuates-inequality

Modi, M., Modi, A. T., \& Hendries, S. (2011). Potential role for wild vegetables in house hold food security: A preliminary case study of KwaZulu-Natal, South Africa. African Journal of Food, Agriculture and Nutrition $40,23$.

Montrone, M., Martorelli, D., Rosato, A., \& Dolcetti, R. (2009). Retinoids as critical modulators of immune functions: New therapeutic perspectives for old compounds. Endocrine, Metabolic \& Immune Disorders-Drug Targets, 9, 113-131. https://doi.org/10.2174/187153009788452435

Niederwieser, J. G. (2004). The sweet potato plant. A guide to sweet potato production in South Africa (p. 2). ARC-Roodeplaat Vegetable and Ornamental Institute, Pretoria.

Simson, S. P., \& Straus, M. C. (2010). Post-harvest technology of horticultural crops. Oxford Book Company/Mehra Offset Press, Delhi.

Thompson, G. J., Van der Mescht, A., Naudè, S. P., Thompson, A. H., Nuijten, E., \& Lubout, P. (1999). Sweet potato and cassava in the Kwazulu Natal Province of South Africa: A baseline study. In M. O. Akoroda, \& J. M. Teri (Eds.), Proceedings of scientific workshop of SARRNET, 17-19 Aug, 1998, Lusaka, Zambia (pp. 40-50). IITA, Ibadan, Nigeria.

UN News. (2013). World population projected to reach 9.6 billion by 2050. UN report. Retrieved October 30, 2014, from http://www.un.org/apps/news/story. asp?NewsID=45165

Van der Merwe, C. (2011). Key challenges for ensuring food security in South Africa's inner cities. AISA PolicyBrief Number 36. AISA (Africa Institute of South Africa).

\section{Copyrights}

Copyright for this article is retained by the author (s), with first publication rights granted to the journal.

This is an open-access article distributed under the terms and conditions of the Creative Commons Attribution license (http://creativecommons.org/licenses/by/4.0/). 